\section{Preplant Lime and Micronutrient Amendments to Pine Bark Affect Growth of Seedlings of Nine Container-grown Tree Species}

\author{
Amy N. Wright ${ }^{1}$, Alex X. Niemiera ${ }^{2}$, J. Roger Harris ${ }^{2}$, and \\ Robert D. Wright ${ }^{3}$ \\ Department of Horticulture, Virginia Polytechnic Institute and State University, \\ Blacksburg, VA 24061-0327
}

Additional index words. nutrition, $\mathrm{pH}$, soilless media, woody ornamentals, nursery crops, Acer sp., Cercis canadensis, Cornus sp., Koelreuteria paniculata, Magnolia $\times$ soulangiana, Nyssa sylvatica, Quercus palustris

\begin{abstract}
The objective of this study was to determine the effects of lime and micronutrient amendments on growth of seedlings of nine container-grown landscape tree species in two pine bark substrates with different $\mathbf{p H s}$. Acer palmatum Thunb. (Japanese maple), Acer saccharum Marsh. (sugar maple), Cercis canadensis L. (redbud), Cornus florida $\mathbf{L}$. (flowering dogwood), Cornus kousa Hance. (kousa dogwood), Koelreuteria paniculata Laxm. (golden-rain tree), Magnolia $\times$ soulangiana Soul.-Bod. 'Lennei' (magnolia), Nyssa sylvatica Marsh. (blackgum), and Quercus palustris Müenchh. (pin oak) were grown from seed in two pine bark substrates with different pHs (pH 4.7 and 5.1) (Expt. 1). Preplant amendment treatments for each of two pine (Pinus taeda L.) bark sources were: with and without dolomitic limestone $\left(3.6 \mathrm{~kg} \cdot \mathrm{m}^{-3}\right)$ and with and without micronutrients $(0.9$ $\left.\mathrm{kg} \cdot \mathrm{m}^{-3}\right)$, and with and without micronutrients $\left(0.9 \mathrm{~kg} \cdot \mathrm{m}^{-3}\right)$, supplied as Micromax. Seedlings were harvested 12 and 19 weeks after seeds were planted, and shoot dry weight and tree height were determined. The same experiment was repeated using two of the nine species from Expt. 1 and pine bark substrates at pH 5.1 and 5.8 (Expt. 2). Seedling shoot dry weight and height were measured 11 weeks after planting. For both experiments, pine bark solutions were extracted using the pour-through method and analyzed for $\mathrm{Ca}, \mathrm{Mg}$, $\mathrm{Fe}, \mathrm{Mn}, \mathrm{Cu}$, and $\mathrm{Zn}$. Growth of all species in both experiments was greater in micronutrient-amended than in lime-amended bark. In general, adding micronutrients increased nutrient concentrations in the pine bark solution, while adding lime decreased them. Effect of bark type on growth in Expt. 1 was variable; however, in Expt. 2, growth was greater in the low pH bark than in the high pH bark. In general, nutrient concentrations in bark solutions were higher in low $\mathrm{pH}$ bark than in high $\mathrm{pH}$ bark for both experiments. Under the $\mathrm{pH}$ conditions of this experiment, micronutrient additions stimulated growth whereas a lime amendment did not.
\end{abstract}

Pine bark is a common container substrate used by nurseries in the southeastern United States and is often preplant amended with lime and micronutrients. In general, the rationale for liming is to increase $\mathrm{pH}$ of acidic bark. Initial bark $\mathrm{pH}$ can vary from 4.0 to 5.5 (personal observation), depending on source, bark age, location within a windrow, and other factors. There is no body of evidence that shows that routine liming of bark is necessary.

\footnotetext{
Received for publication 6 July 1998. Accepted for publication 30 Nov. 1998. Appreciation is extended to Jody K. Fanelli and Joyce Shelton for valuable assistance. Use of trade names does not imply endorsement of products named to the exclusion of other products that may also be suitable. The cost of publishing this paper was defrayed in part by the payment of page charges. Under postal regulations, this paper therefore must be hereby marked advertisement solely to indicate this fact.

${ }^{1}$ Graduate Student.

${ }^{2}$ Associate Professor

${ }^{3}$ Professor.
}

To date, most research on the effects of lime and micronutrient amendments on soilless substrates and plant growth has been confined to shrub species, and the results have been inconsistent. Sartain and Ingram (1984) showed that lime additions reduced growth of Juniperus horizontalis Moench 'Andorra Compacta' in a pine bark-peat-sand substrate. Yeager and Ingram (1983) found that growth of Ilexcrenata Thunb. 'Helleri' and Juniperus horizontalis 'Plumosa' in a pine bark-peat-sand substrate was best without addition of lime, while lime had no effect on Rhododendron obtusum (Lindl.) Planch. 'Hino-Crimson' growth. Chrustic and Wright (1983) reported that growth of Ilex crenata 'Helleri' and Rhododendron obtusum 'Rosebud' in pine bark was not increased by liming, and was inhibited at high rates.

Wright and Hinesley (1991) showed that liming improved the growth of Juniperus virginiana $\mathrm{L}$. in a pine bark-sand substrate; micronutrients inhibited growth in the absence of lime, but had no effect in its presence. Leda (1986) observed no growth response of
Ilex crenata 'Helleri', Juniperus procumbens (Endl.) Miq. 'Nana', and Ligustrum lucidum Ait. to micronutrient additions to pine bark

Because of the advent of the pot-in-pot tree production system, as well as recent favorable market forces, the number of landscape trees being produced in containers is rapidly increasing (personal observation). Very little information, however, exists on the chemical substrate requirements for container-grown tree species. Research is therefore needed to determine the effects of lime and micronutrient amendments on tree growth. Since bark $\mathrm{pH}$ varies with source, the recommendation for substrate amendments may be dependent on $\mathrm{pH}$. The purpose of this work was to determine the effects of lime and micronutrient amendment on the seedling growth of nine tree species grown in pine bark substrates with different $\mathrm{pHs}$.

\section{Materials and Methods}

Expt. 1. Nine species of landscape tree seedlings were grown in each of two pine bark (Pinus taeda) substrates (pH 4.7 and 5.1). Species were Acer palmatum (Japanese maple), Acer saccharum (sugar maple), Cercis canadensis (redbud), Cornus florida (flowering dogwood), Cornus kousa (kousa dogwood), Koelreuteria paniculata (golden-rain tree), Magnolia $\times$ soulangiana 'Lennei' (saucer magnolia), Nyssa sylvatica (blackgum), and Quercus palustris (pin oak). Amendment treatments for the two pine bark types were: with and without lime and with and without micronutrients, in a 2 (pine bark) $\times 2$ (lime) $\times 2$ (micronutrients) factorial arrangement. Ground dolomitic limestone (James River Limestone Co., Buchanan, Va.) (18\% Ca, $10 \% \mathrm{Mg}$ ) with a calcium carbonate equivalence of $100 \%$ was applied at a rate of $3.6 \mathrm{~kg} \cdot \mathrm{m}^{-3}$. Proportions of lime passing through indicated mesh size (number of holes per inch) were: size $8,100 \%$; size $10,100 \%$; size $20,90 \%$; size $50,55 \%$; size 60 , $50 \%$; and size 100, 35\%. Micronutrients (Micromax $^{\mathrm{TM}}$; The Scotts Co., Marysville, Ohio), applied at a rate of $0.9 \mathrm{~kg} \cdot \mathrm{m}^{-3}$, had the following composition: $12 \% \mathrm{~S}, 0.1 \% \mathrm{Bo}\left(\mathrm{Na}_{2}\right.$ $\left.\mathrm{B}_{4} \mathrm{O}_{7}\right), 0.5 \% \mathrm{Cu}\left(\mathrm{CuSO}_{4}\right), 12 \% \mathrm{Fe}\left(\mathrm{FeSO}_{4}\right)$, $2.5 \% \mathrm{Mn}\left(\mathrm{MnSO}_{4}\right), 0.05 \% \mathrm{Mo}\left(\mathrm{Na}_{2} \mathrm{MoO}_{4}\right)$, and $1 \% \mathrm{Zn}\left(\mathrm{ZnSO}_{4}\right)$. Micronutrients and lime were preplant-incorporated using a substrate mixing apparatus. Initial pine bark $\mathrm{pH}$ was 4.7 (low) (Summit Bark Plant, Waverly, Va.) and 5.1 (high) (Summit Bark Plant, Lewisburg, N.C.). Bark physical properties (Niemiera et al., 1994) were: air space $=25.9 \%$ and $24.3 \%$; bulk density $=213$ and $200 \mathrm{~kg} \cdot \mathrm{m}^{-3}$; total porosity $=71.2 \%$ and $79.8 \%$; container (waterholding) capacity $=45.4 \%$ and $55.5 \%$ for low and high $\mathrm{pH}$ bark, respectively. Solution element concentrations of the first bark solution extraction of controls (unamended bark) of Expts. 1 and 2 indicated the bark's inherent element supply. Concentrations of the low and high $\mathrm{pH}$ bark in Expt. 1, respectively, were (in $\left.\mathrm{mg} \cdot \mathrm{L}^{-1}\right): 37$ and $32 \mathrm{Ca}, 8.2$ and $4.3 \mathrm{Mg}, 0.90$ and $0.23 \mathrm{Fe}, 0.58$ and $0.13 \mathrm{Mn}, 0.40$ and 0.30 $\mathrm{Cu}$, and 0.20 and 0.17 Zn. In Expt. 2, the same elements were supplied in similar relative ini- 
tial concentrations, with concentrations in Expt. 2 being slightly lower than those in Expt. 1 (data not shown).

Treatments were assigned in a completely randomized design with three single-container replications per treatment. Plastic, 11-L containers (26.7-cm diameter, 24-cm height) were filled with each lime-micronutrient-bark combination. Each species was treated as a separate experiment, and all experiments were conducted concurrently. About 30 seeds (Sheffield's Seed Co., Locke, N.Y.) per container were sown just below the substrate surface on 17 Jan. 1997 (week 0). Seeds of all species germinated in 1 to 2 weeks and seedlings were thinned at week 6 to $\approx 15$ of uniform size per container $(\approx 45$ seedlings per treatment). All seedlings were irrigated as needed with a $500-\mathrm{mL}$ fertilizer solution of 300 $\mathrm{mg} \cdot \mathrm{L}^{-1} \mathrm{~N}\left(\right.$ as $\left.\mathrm{NH}_{4} \mathrm{NO}_{3}\right), 45 \mathrm{mg} \cdot \mathrm{L}^{-1} \mathrm{P}\left(\right.$ as $\left.\mathrm{H}_{3} \mathrm{PO}_{4}\right)$, and $100 \mathrm{mg} \cdot \mathrm{L}^{-1} \mathrm{~K}$ (as $\mathrm{KCl}$ ). Calcium and magnesium concentrations in the irrigation water were 10.2 and $4.2 \mathrm{mg} \cdot \mathrm{L}^{-1}$, respectively, and micronutrient concentrations were (in $\left.\mathrm{mg} \cdot \mathrm{L}^{-1}\right) 0 \mathrm{Fe}, 0 \mathrm{Mn}, 0.04 \mathrm{Zn}$, and $0.002 \mathrm{Cu}$. Irrigation water alkalinity was $36 \mathrm{mg} \cdot \mathrm{L}^{-1}$. All plants were greenhouse-grown on raised benches.

Pine bark solutions were extracted at weeks 2,7 , and 18. At each date, solution was extracted from six containers (using more than one species) per lime-micronutrient-bark treatment combination, using the pour-through method (Yeager et al., 1983), by applying 500 $\mathrm{mL}$ water to the substrate surface $1 \mathrm{~h}$ after irrigation and collecting the substrate leachate. Leachate $\mathrm{pH}$ was measured, and filtered solutions were analyzed for $\mathrm{Ca}, \mathrm{Mg}, \mathrm{Fe}, \mathrm{Mn}, \mathrm{Zn}$, and Cu using inductively coupled plasma analysis. Week 18 pour-through solutions were also analyzed for $\mathrm{NO}_{3}-\mathrm{N}$ and $\mathrm{NH}_{4}-\mathrm{N}$ using ionspecific electrodes.

To continue the experiment for some species, all plants except one (randomly selected) per container for A. palmatum, A. saccharum, C. canadensis, C. florida, and $Q$. palustris were harvested at week 12 , and shoot dry weight and height were determined. For other species, all seedlings were harvested at week 12 , and the same measurements were taken. At week 19, the remaining seedling of each of the above listed species was harvested, and shoot dry weight and height were determined. Samples of most recently matured leaves of $Q$. palustris, $K$. paniculata, and $C$. florida were collected and analyzed as follows. For each sample, $250 \mathrm{mg}$ of dried and ground leaf tissue was ashed $(\approx 4 \mathrm{~h})$ at $450{ }^{\circ} \mathrm{C}$, the ash was dissolved in $20 \mathrm{~mL} 0.3 \mathrm{~N} \mathrm{HNO}_{3}$, and the solution was filtered and brought up to $50-\mathrm{mL}$ volume with $0.3 \mathrm{~N} \mathrm{HNO}_{3}$. These solutions were analyzed for $\mathrm{Ca}, \mathrm{Mg}, \mathrm{Fe}, \mathrm{Mn}, \mathrm{Zn}$, and $\mathrm{Cu}$ as described above. All data were analyzed using analysis of variance (ANOVA) (SAS Institute, 1985); Tukey's HSD $(P \leq 0.05 \%)$ was used for mean separation.

Expt. 2. The above experiment was repeated beginning on 17 July 1997 using $K$. paniculata and $Q$. palustris, and bark from the same sources listed previously; the initial $\mathrm{pHs}$ of the low and high $\mathrm{pH}$ barks were 5.1 and 5.8, respectively. Seedlings were thinned at week 6 to five seedlings of uniform size per container. All plants were harvested at week 11 for shoot dry weight and height. Pine bark solutions were extracted using the pour-through method at weeks 3 and 10 and analyzed as described above. All data were analyzed using ANOVA (SAS Institute, 1985): Tukey's HSD $(P \leq 0.05 \%)$ was used for mean separation.

\section{Results}

Micronutrient effect. Analysis of variance of dry-weight data for all species in Expt. 1 (Table 1; shoot height data paralleled those for dry weight) and for dry weight and shoot height data for $K$. paniculata and $Q$. palustris in Expt. 2 (Table 2) indicated significant micronutrient effects. Both weight and height of all species in both experiments were greater when micronutrients were added (Tables 3 and 4). Depending on species, addition of micronutrients increased dry weight from $21 \%$ for A. palmatum to $88 \%$ for $Q$. palustris. Similar patterns were seen at week 19 in Expt. 1 (data not shown). In addition to the significant main effect for micronutrients, interactions between micronutrient $\times$ bark type and micronutrient $\times$ lime were significant. We addressed the micronutrient main effect despite interactions, because the differences were quantitative, rather than qualitative. A micro-

Table 1. Significance ( $P$ value) of main effects of micronutrients, lime, bark source, and their interactions on shoot dry weight (week 12) of nine tree species, Expt. 1.

\begin{tabular}{lccccccc}
\hline \hline Species & & & & Lime $\times$ & Lime $\times$ & Micros $\times$ & Lime $\times$ \\
Micronutrients & Lime & Bark & Micros & Bark & Bark & Micros $\times$ Bark \\
\hline A. palmatum & 0.0001 & 0.1076 & 0.3736 & 0.1860 & 0.2087 & 0.3054 & 0.8737 \\
A. saccharum & 0.0001 & 0.0116 & 0.4720 & 0.5108 & 0.1874 & 0.1518 & 0.0685 \\
C. canadensis & 0.0001 & 0.0066 & 0.3299 & 0.2028 & 0.2271 & 0.1042 & 0.5503 \\
& & & & & & & \\
C. kousa & 0.0018 & 0.0091 & 0.0024 & 0.4862 & 0.0876 & 0.0518 & 0.8972 \\
C. florida & 0.0001 & 0.0685 & 0.2000 & 0.5926 & 0.2962 & 0.3289 & 0.9905 \\
K. paniculata & 0.0001 & 0.0696 & 0.8096 & 0.7661 & 0.1649 & 0.0150 & 0.9209 \\
M. $\times$ soulangiana & 0.0001 & 0.0245 & 0.0003 & 0.3582 & 0.0615 & 0.0027 & 0.0767 \\
N. sylvatica & 0.0001 & 0.1790 & 0.2504 & 0.1047 & 0.0080 & 0.0303 & 0.6029 \\
$Q$. palustris & 0.0038 & 0.4304 & 0.4880 & 0.9611 & 0.5714 & 0.0184 & 0.7092 \\
\hline
\end{tabular}

Table 2. Significance ( $P$ values) of main effects of micronutrients, lime, bark source, and their interactions on shoot dry weight and height (week 11) for Koelreuteria paniculata and Quercus palustris, Expt. 2.

\begin{tabular}{|c|c|c|c|c|}
\hline \multirow[b]{2}{*}{ Interaction } & \multicolumn{2}{|c|}{ K. paniculata } & \multicolumn{2}{|c|}{ Q. palustris } \\
\hline & Dry weight & Height & Dry weight & Height \\
\hline Micronutrients & 0.0001 & 0.0001 & 0.001 & 0.0001 \\
\hline Lime & 0.0008 & 0.0001 & 0.1091 & 0.0305 \\
\hline Bark & 0.0007 & 0.0001 & 0.0001 & 0.0001 \\
\hline Lime $\times$ Micro & 0.0001 & 0.0433 & 0.0192 & 0.0043 \\
\hline Lime $\times$ Bark & 0.1423 & 0.4537 & 0.1126 & 0.0807 \\
\hline Micros $\times$ Bark & 0.0705 & 0.4537 & 0.0417 & 0.0212 \\
\hline Lime $\times$ Micros $\times$ Bark & 0.0005 & 0.0287 & 0.6940 & 0.3706 \\
\hline
\end{tabular}

Table 3. Main effects of micronutrients, lime, and bark type on shoot dry weight (week 12) of nine tree species, Expt. 1 .

\begin{tabular}{|c|c|c|c|c|c|c|}
\hline \multirow[b]{2}{*}{ Species } & \multicolumn{2}{|c|}{ Micronutrients } & \multicolumn{2}{|c|}{ Lime } & \multicolumn{2}{|c|}{ Bark } \\
\hline & + & - & + & - & Low pH & High pH \\
\hline \multicolumn{7}{|c|}{ Shoot dry weight (g) } \\
\hline A. palmatum & $0.66 \mathrm{a}^{\mathrm{z}, \mathrm{y}}$ & $0.19 \mathrm{~b}$ & $0.38 \mathrm{a}$ & $0.46 \mathrm{a}$ & $0.44 \mathrm{a}$ & $0.40 \mathrm{a}$ \\
\hline A. saccharum & $0.55 \mathrm{a}$ & $0.30 \mathrm{~b}$ & $0.39 \mathrm{~b}$ & $0.46 \mathrm{a}$ & $0.42 \mathrm{a}$ & $0.44 \mathrm{a}$ \\
\hline C. canadensis & $0.77 \mathrm{a}$ & $0.38 \mathrm{~b}$ & $0.50 \mathrm{~b}$ & $0.64 \mathrm{a}$ & $0.60 \mathrm{a}$ & $0.55 \mathrm{a}$ \\
\hline C. kousa & $0.67 \mathrm{a}$ & $0.34 \mathrm{~b}$ & $0.37 \mathrm{~b}$ & $0.63 \mathrm{a}$ & $0.34 \mathrm{~b}$ & $0.66 \mathrm{a}$ \\
\hline C. florida & $0.80 \mathrm{a}$ & $0.34 \mathrm{~b}$ & $0.50 \mathrm{~b}$ & $0.63 \mathrm{a}$ & $0.48 \mathrm{~b}$ & $0.66 \mathrm{a}$ \\
\hline$Q$. palustris & $1.44 \mathrm{a}$ & $1.27 \mathrm{~b}$ & $1.34 \mathrm{a}$ & $1.38 \mathrm{a}$ & $1.34 \mathrm{a}$ & $1.38 \mathrm{a}$ \\
\hline K. paniculata & $1.2 \mathrm{a}$ & $0.52 \mathrm{~b}$ & $0.80 \mathrm{a}$ & $0.91 \mathrm{a}$ & $0.85 \mathrm{a}$ & $0.86 \mathrm{a}$ \\
\hline M. Xsoulangiana & $0.30 \mathrm{a}$ & $0.22 \mathrm{~b}$ & $0.24 \mathrm{~b}$ & $0.28 \mathrm{a}$ & $0.23 \mathrm{~b}$ & $0.29 \mathrm{a}$ \\
\hline N. sylvatica & $0.22 \mathrm{a}$ & $0.13 \mathrm{~b}$ & $0.16 \mathrm{~b}$ & $0.20 \mathrm{a}$ & $0.17 \mathrm{a}$ & $0.18 \mathrm{a}$ \\
\hline \multicolumn{7}{|c|}{ Shoot height $(\mathrm{cm})$} \\
\hline A. palmatum & $25.8 a^{z, y}$ & $10.1 \mathrm{~b}$ & $16.7 \mathrm{a}$ & $19.2 \mathrm{a}$ & $19.4 \mathrm{a}$ & $16.5 \mathrm{~b}$ \\
\hline A. saccharum & $15.2 \mathrm{a}$ & $11.1 \mathrm{~b}$ & $12.6 \mathrm{a}$ & $13.7 \mathrm{a}$ & $13.0 \mathrm{a}$ & $13.3 \mathrm{a}$ \\
\hline C. canadensis & $20.2 \mathrm{a}$ & $13.3 \mathrm{~b}$ & $15.4 \mathrm{~b}$ & $18.1 \mathrm{a}$ & $17.7 \mathrm{a}$ & $15.8 \mathrm{a}$ \\
\hline C. kousa & $12.7 \mathrm{a}$ & $7.6 \mathrm{~b}$ & $9.0 \mathrm{~b}$ & $11.4 \mathrm{a}$ & $8.8 \mathrm{~b}$ & $11.6 \mathrm{a}$ \\
\hline C. florida & $15.6 \mathrm{a}$ & $9.9 \mathrm{~b}$ & $12.0 \mathrm{~b}$ & $13.5 \mathrm{a}$ & $12.5 \mathrm{a}$ & $13.0 \mathrm{a}$ \\
\hline$Q$. palustris & $24.3 \mathrm{a}$ & $22.2 \mathrm{~b}$ & $22.4 \mathrm{~b}$ & $24.2 \mathrm{a}$ & $23.5 \mathrm{a}$ & $23.1 \mathrm{a}$ \\
\hline K. paniculata & $10.4 \mathrm{a}$ & $6.4 \mathrm{~b}$ & $7.8 \mathrm{~b}$ & $9.0 \mathrm{a}$ & $8.2 \mathrm{a}$ & $8.6 \mathrm{a}$ \\
\hline M. Xsoulangiana & $6.5 \mathrm{a}$ & $5.2 \mathrm{~b}$ & $5.6 \mathrm{a}$ & $6.1 \mathrm{a}$ & $5.3 \mathrm{~b}$ & $6.3 \mathrm{a}$ \\
\hline N. sylvatica & $6.1 \mathrm{a}$ & $4.9 \mathrm{~b}$ & $5.3 \mathrm{~b}$ & $5.8 \mathrm{a}$ & $5.2 \mathrm{~b}$ & $5.8 \mathrm{a}$ \\
\hline
\end{tabular}

${ }^{\mathrm{z}}$ Means for $\mathrm{n}=12$ observations.

yeans separation within rows and parameters by Tukey's HSD, $P \leq 0.05$. 
Table 4. Main effects of micronutrients, lime, and bark type on shoot dry weight and height (week 11) of Quercus palustris and Koelreuteria paniculata, Expt. 2.

\begin{tabular}{|c|c|c|c|c|c|c|c|c|c|c|c|c|}
\hline \multirow[b]{3}{*}{ Species } & \multicolumn{6}{|c|}{ Shoot dry weight (g) } & \multicolumn{6}{|c|}{ Shoot height $(\mathrm{cm})$} \\
\hline & \multicolumn{2}{|c|}{ Micronutrient } & \multicolumn{2}{|c|}{ Lime } & \multicolumn{2}{|c|}{ Bark pH } & \multicolumn{2}{|c|}{ Micronutrients } & \multicolumn{2}{|c|}{ Lime } & \multicolumn{2}{|c|}{ Bark pH } \\
\hline & + & - & + & - & Low & High & + & - & + & - & Low & High \\
\hline Q. palustris & $3.1 \mathrm{a}^{\mathrm{z}, \mathrm{y}}$ & $2.5 \mathrm{~b}$ & $2.7 \mathrm{a}$ & $2.9 \mathrm{a}$ & $3.1 \mathrm{a}$ & $2.5 \mathrm{~b}$ & $32.3 \mathrm{a}$ & $27.2 \mathrm{~b}$ & $28.9 \mathrm{~b}$ & $30.6 \mathrm{a}$ & $32.0 \mathrm{a}$ & $24.7 \mathrm{~b}$ \\
\hline K. paniculata & $2.4 \mathrm{a}$ & $1.2 \mathrm{~b}$ & $1.7 \mathrm{~b}$ & $2.0 \mathrm{a}$ & $2.0 \mathrm{a}$ & $1.7 \mathrm{~b}$ & $11.4 \mathrm{a}$ & $7.4 \mathrm{~b}$ & $8.4 \mathrm{~b}$ & $10.4 \mathrm{a}$ & $10.5 \mathrm{a}$ & $8.3 \mathrm{~b}$ \\
\hline
\end{tabular}

${ }^{2}$ Means for $\mathrm{n}=12$ observations

yean separation within species and factors by Tukey's HSD, $P \leq 0.05$.

nutrient $\times$ bark interaction was significant for $K$. paniculata, $M$. $\times$ soulangiana, $Q$. palustris, N. sylvatica, C. kousa in Expt. 1 (Table 1) and for $K$. paniculata and $Q$. palustris in Expt. 2 (Table 2), reflecting the greater increase in dry weight from adding micronutrients to high than to low $\mathrm{pH}$ bark (Fig. 1A; K. paniculata data). A significant micronutrient $\times$ lime interaction for both species in Expt. 2 (Table 2) reflected the greater dry-weight response to micronutrients when lime was added (Fig. 1B; $K$. paniculata data). When micronutrients were added, neither $\mathrm{pH}$ nor lime had a significant effect on dry weight (Fig. 1 A and B) (statistics not shown).

In both experiments, addition of micronutrients increased pine bark solution $\mathrm{Ca}, \mathrm{Mg}$, $\mathrm{Fe}, \mathrm{Mn}, \mathrm{Cu}$, and $\mathrm{Zn}$ concentrations (averaged over species; Table 5) from $8.3 \%$ (Mn) to $62 \%$ (Fe). In contrast, solution $\mathrm{NO}_{3}-\mathrm{N}$ concentration (Expt. 1) was lower when micronutrients were added (Table 5). In both experiments, addition of micronutrients lowered the $\mathrm{pH} 0.2$ units. Foliage of plants grown without micronutrients appeared chlorotic compared with that of plants grown with micronutrients. In general, adding micronutrients increased leaf micronutrient concentrations, whereas $\mathrm{Ca}$ and $\mathrm{Mg}$ leaf concentrations were variable. Data for $Q$.palustris are shown in Table 6 as a representative treatment response, since the responses for $K$. paniculata and C. florida were generally similar; data not shown.

Lime effect. Addition of lime reduced either shoot dry weight or height for all species (except Japanese maple) at week 12 in Expt. 1 and for both species in Expt. 2 (Tables 3 and 4). By week 19 in Expt. 1, either height or dry weight for all species was lower in the presence of added lime (data not shown). In addition to the significant main effect for lime, a micronutrient $\times$ lime interaction was also significant for both species in Expt. 2 (Table 2; previously described). The main effect was addressed despite the interaction for the same reason given in the previous micronutrient section. In Expts. 1 and 2 (week 7 and week 3, respectively), pine bark solution $\mathrm{pH}$ was 0.6 units higher in lime-amended bark (Table 5). This result was consistent with $\mathrm{pH}$ values determined throughout both experiments (data not shown). Solution $\mathrm{Mg}$ concentration increased with lime additions in both Expt. 1 $(54 \%)$ and $2(72 \%)$ (Table 5). Addition of lime reduced solution $\mathrm{Ca}$ concentration $17 \%$ in Expt. 1, but had no effect in Expt. 2 (Table 5). Liming reduced solution $\mathrm{Fe}, \mathrm{Mn}, \mathrm{Cu}$, and $\mathrm{Zn}$ concentrations in both Expt. 1 and 2 (Table 5), and increased solution $\mathrm{NO}_{3}-\mathrm{N}$ concentration $81 \%$, while reducing $\mathrm{NH}_{4}-\mathrm{N}$ concentration 99\% (Expt. 1) (Table 5). In general, no trends
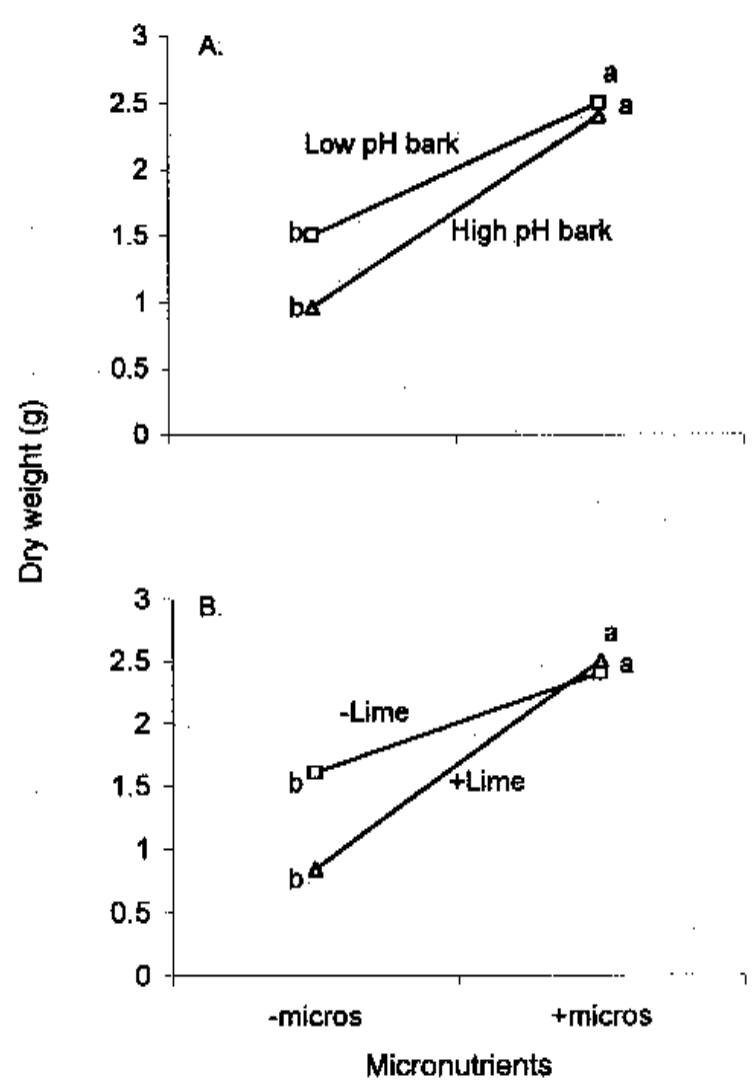

Fig. 1. Interaction of ( $\mathbf{A})$ micronutrient addition and bark $\mathrm{pH}$ and of $(\mathbf{B})$ micronutrient addition and lime on shoot dry weight of Koelreuteria paniculata, Expt. 2. Each point is the mean of 12 observations. Mean separation within (A) bark type and (B) lime treatment by Tukey's HSD, $P \leq 0.05$. Interaction significant at $P \leq 0.05$.

were evident for leaf element concentrations relative to lime treatments across species. However, liming increased leaf $\mathrm{Mg}$ concentration (Table 6).

Bark effect. In Expt. 1, the main effect of bark type was more variable than were main effects of lime and micronutrient additions. In Expt. 2, both shoot dry weight and height for both species were higher in low $\mathrm{pH}$ bark (Table 4). In addition, plants grown in high $\mathrm{pH}$ bark in Expt. 2 appeared chlorotic, whereas those grown in the lower $\mathrm{pH}$ bark appeared normal. Solution element concentrations were lower in the high $\mathrm{pH}$ bark (Table 5). Calcium concentrations were $37 \%$ and $16 \%$ lower in Expts. 1 and 2, respectively, and Mn concentrations were extremely low in the high $\mathrm{pH}$ bark in both experiments. Initial solution element concentrations (Expt. 1) for unamended low $\mathrm{pH}$ bark and high $\mathrm{pH}$ bark, respectively, were $\left(\mathrm{mg} \cdot \mathrm{L}^{-1}\right): 37$ and $32 \mathrm{Ca}, 8.2$ and $4.3 \mathrm{Mg}$, 0.90 and $0.23 \mathrm{Fe}, 0.58$ and $0.13 \mathrm{Mn}, 0.40$ and $0.30 \mathrm{Cu}$, and 0.20 and $0.17 \mathrm{Zn}$. In Expt. 2, the same elements were supplied in similar but slightly lower concentrations (data not shown). Leaf element concentrations, with the exception of $\mathrm{Mn}$, were generally higher for plants grown in low $\mathrm{pH}$ bark (Table 6).

\section{Discussion}

Of all treatments, amending bark with micronutrients resulted in the best growth responses for all species (Tables 3 and 4). Adding micronutrients increased both bark solution (Table 5) and leaf micronutrient concentration (Table 6). However, few elements were present in tissue in adequate concentrations, possibly due to a dilution effect often observed for element concentrations in fast-growing tissue (Mengel and Kirkby, 1987). In the absence of added micronutrients, plants were small (Tables 3 and 4) and usually chlorotic, probably because of micronutrient deficiency; this was supported by the relatively low substrate solution (Table 5) and corresponding leaf tissue micronutrient concentrations (Table 6). Pine bark solution $\mathrm{Ca}$ concentrations for 
Table 5. Main effects of micronutrients, lime, and bark type on pine bark solution $\mathrm{pH}$ and element concentrations $^{\mathrm{z}}$ across all species. ${ }^{\mathrm{y}}$

\begin{tabular}{|c|c|c|c|c|c|c|}
\hline \multirow[b]{2}{*}{ Observation } & \multicolumn{2}{|c|}{ Micronutrients } & \multicolumn{2}{|c|}{ Lime } & \multicolumn{2}{|c|}{ Bark pH } \\
\hline & + & - & + & - & Low & High \\
\hline \multicolumn{7}{|c|}{ Expt. 1, week 7} \\
\hline $\mathrm{pH}$ & $5.1 \mathrm{a}^{\mathrm{x}, \mathrm{w}}$ & $5.3 \mathrm{a}$ & $5.5 \mathrm{a}$ & $4.9 \mathrm{~b}$ & $5.1 \mathrm{~b}$ & $5.3 \mathrm{a}$ \\
\hline $\mathrm{Ca}$ & $73.9 \mathrm{a}$ & $31.5 \mathrm{~b}$ & $47.8 \mathrm{~b}$ & $57.6 \mathrm{a}$ & $60.9 \mathrm{a}$ & $44.5 \mathrm{~b}$ \\
\hline $\mathrm{Mg}$ & $27.2 \mathrm{a}$ & $11.0 \mathrm{~b}$ & $24.7 \mathrm{a}$ & $13.4 \mathrm{~b}$ & $25.0 \mathrm{a}$ & $13.1 \mathrm{~b}$ \\
\hline $\mathrm{Fe}$ & $0.08 \mathrm{a}$ & $0.05 \mathrm{~b}$ & $0.05 \mathrm{~b}$ & $0.08 \mathrm{a}$ & $0.08 \mathrm{a}$ & $0.05 \mathrm{~b}$ \\
\hline $\mathrm{Mn}$ & $1.80 \mathrm{a}$ & $0.15 b$ & $0.46 \mathrm{~b}$ & $1.49 \mathrm{a}$ & $1.8 \mathrm{a}$ & $0.11 \mathrm{~b}$ \\
\hline $\mathrm{Cu}$ & $0.02 \mathrm{a}$ & $0.01 \mathrm{~b}$ & $0.01 \mathrm{~b}$ & $0.02 \mathrm{a}$ & $0.02 \mathrm{a}$ & $0.01 \mathrm{~b}$ \\
\hline $\mathrm{Zn}$ & $0.31 \mathrm{a}$ & $0.09 \mathrm{~b}$ & $0.09 \mathrm{~b}$ & $0.30 \mathrm{a}$ & $0.28 \mathrm{a}$ & $0.12 \mathrm{~b}$ \\
\hline $\mathrm{NO}_{3}-\mathrm{N}$ & $88.1 \mathrm{~b}$ & $104.0 \mathrm{a}$ & $106.1 \mathrm{a}$ & $86.0 \mathrm{~b}$ & $84.0 \mathrm{~b}$ & $108.0 \mathrm{a}$ \\
\hline $\mathrm{NH}_{4}-\mathrm{N}$ & $2.3 \mathrm{a}$ & $5.6 \mathrm{a}$ & $0.04 \mathrm{~b}$ & $7.9 \mathrm{a}$ & $4.4 \mathrm{a}$ & $3.5 \mathrm{a}$ \\
\hline \multicolumn{7}{|c|}{ Expt. 2, week 3} \\
\hline $\mathrm{pH}$ & $5.6 \mathrm{~b}^{\mathrm{x}}$ & $5.8 \mathrm{a}$ & $6.0 \mathrm{a}$ & $5.4 \mathrm{~b}$ & $5.4 \mathrm{~b}$ & $6.0 \mathrm{a}$ \\
\hline $\mathrm{Ca}$ & $175.3 \mathrm{a}$ & $58.3 \mathrm{~b}$ & $118.9 \mathrm{a}$ & $114.8 \mathrm{a}$ & $125.7 \mathrm{a}$ & $107.9 \mathrm{~b}$ \\
\hline $\mathrm{Mg}$ & $47.0 \mathrm{a}$ & $14.5 \mathrm{~b}$ & $35.8 \mathrm{a}$ & $25.8 \mathrm{~b}$ & $37.5 \mathrm{a}$ & $24.0 \mathrm{~b}$ \\
\hline $\mathrm{Fe}$ & $0.11 \mathrm{a}$ & $0.08 \mathrm{~b}$ & $0.07 \mathrm{~b}$ & $0.12 \mathrm{a}$ & $0.11 \mathrm{a}$ & $0.08 \mathrm{~b}$ \\
\hline $\mathrm{Mn}$ & $2.9 \mathrm{a}$ & $0.17 \mathrm{~b}$ & $0.64 \mathrm{~b}$ & $2.4 \mathrm{a}$ & $3.0 \mathrm{a}$ & $0.02 \mathrm{~b}$ \\
\hline $\mathrm{Cu}$ & $0.02 \mathrm{a}$ & $0.008 \mathrm{~b}$ & $0.01 \mathrm{~b}$ & $0.02 \mathrm{a}$ & $0.02 \mathrm{a}$ & $0.01 \mathrm{~b}$ \\
\hline $\mathrm{Zn}$ & $0.47 \mathrm{a}$ & $0.08 \mathrm{~b}$ & $0.11 \mathrm{~b}$ & $0.44 \mathrm{a}$ & $0.46 \mathrm{a}$ & $0.12 b$ \\
\hline
\end{tabular}

${ }^{2}$ Elemental concentration expressed in $\mathrm{mg} \cdot \mathrm{L}^{-1}$.

${ }^{\mathrm{y}}$ Data are representative of pour-through data taken at weeks 2 and 18 in Expt. 1, and week 10 in Expt. 2. ${ }^{\mathrm{x}}$ Means for $\mathrm{n}=24$ observations.

wMean separation within factors and times of sampling by Tukey's HSD, $P \leq 0.05$.

Table 6. Effects of micronutrients, lime, and bark type on elemental concentrations in Quercus palustris leaf tissue at week 19 harvest, Expt. 1.

\begin{tabular}{|c|c|c|c|c|c|c|}
\hline \multirow[b]{2}{*}{ Element } & \multicolumn{2}{|c|}{ Micronutrients } & \multicolumn{2}{|c|}{ Lime } & \multicolumn{2}{|c|}{ Bark pH } \\
\hline & + & - & + & - & Low & High \\
\hline$\overline{\mathrm{Ca}(\%)}$ & $0.55 \mathrm{a}^{\mathrm{z}, \mathrm{y}}$ & $0.49 \mathrm{~b}$ & $0.51 \mathrm{a}$ & $0.54 \mathrm{a}$ & $0.54 \mathrm{a}$ & $0.50 \mathrm{~b}$ \\
\hline $\operatorname{Mg}(\%)$ & $0.15 \mathrm{~b}$ & $0.19 \mathrm{a}$ & $0.22 \mathrm{a}$ & $0.12 b$ & $0.18 \mathrm{a}$ & $0.16 \mathrm{~b}$ \\
\hline $\mathrm{Fe}\left(\mu \mathrm{g} \cdot \mathrm{g}^{-1}\right)$ & $41.8 \mathrm{a}$ & $36.5 \mathrm{~b}$ & $41.4 \mathrm{a}$ & $36.9 \mathrm{~b}$ & $43.6 \mathrm{a}$ & $34.7 \mathrm{~b}$ \\
\hline $\operatorname{Mn}\left(\mu \mathrm{g} \cdot \mathrm{g}^{-1}\right)$ & $221.8 \mathrm{a}$ & $150.5 \mathrm{~b}$ & $167.4 \mathrm{~b}$ & $204.8 \mathrm{a}$ & $127 \mathrm{~b}$ & $245 \mathrm{a}$ \\
\hline $\mathrm{Cu}\left(\mu \mathrm{g} \cdot \mathrm{g}^{-1}\right)$ & $5.53 \mathrm{a}$ & $3.83 \mathrm{~b}$ & $4.93 \mathrm{a}$ & $4.40 \mathrm{~b}$ & $5.5 \mathrm{a}$ & $3.9 \mathrm{~b}$ \\
\hline $\mathrm{Zn}\left(\mu \mathrm{g} \cdot \mathrm{g}^{-1}\right)$ & $38.4 \mathrm{a}$ & $31.7 \mathrm{~b}$ & $40.2 \mathrm{a}$ & $29.9 \mathrm{~b}$ & $39.2 \mathrm{a}$ & $31.0 \mathrm{~b}$ \\
\hline
\end{tabular}

${ }^{2}$ Means for $\mathrm{n}=12$ observations.

'Mean separation within factors by Tukey's HSD, $P \leq 0.05$.

both bark types were higher when micronutrients were added. The micronutrient source (Micromax) contained only trace amounts of $\mathrm{Ca}$ (data not shown), thereby eliminating Micromax as an appreciable source of $\mathrm{Ca}$. However, the increased Ca levels were probably not responsible for the increase in plant growth, since Starr and Wright (1984) reported that substrate solution Ca concentrations of 5 to $10 \mathrm{mg} \cdot \mathrm{L}^{-1}$ were sufficient for maximum dry weight of Ilex crenata Thunb. 'Helleri'. In both experiments, Ca solution concentration for unamended bark was at least $28 \mathrm{mg} \cdot \mathrm{L}^{-1}$ (with $\approx 10 \mathrm{mg} \cdot \mathrm{L}^{-1}$ Ca supplied by the irrigation water).

Amending pine bark with lime failed to increase growth at any time, and had suppressed growth for most species in Expt. 1 by week 12 (Table 3) and for all species in Expt. 1 by the final harvest date (data not shown). Both species in Expt. 2 grew less when pine bark was amended with lime (Table 4). Plants in the lime-only treatment were particularly chlorotic (visual observation) and had lower leaf micronutrient concentrations than did plants receiving other treatments (data not shown). This effect of lime additions on shoot nutrient concentrations probably resulted from reduced micronutrient concentrations in bark solutions in the presence of lime, which increases substrate $\mathrm{pH}$ (Table 5). This can cause "lime-induced chlorosis" (Mengel and Kirkby, 1987). An increase in $\mathrm{pH}$ can reduce nutrient availability by precipitating micronutrient cations, as well as increasing adsorption of cations to the substrate particle as a result of higher cation exchange capacity (Brady, 1990; Daniels and Wright, 1988). The micronutrient $\times$ lime interaction in Expt. 2 (Fig. 1B) indicated that adding micronutrients to bark, regardless of lime treatment, increased growth; however, the increase was greater when lime was added. Growth in bark without micronutrients and with lime was very limited compared to that in bark without any amendments, for the reasons given above. When micronutrients were added, liming did not affect growth (statistics not shown). Growth in the bark with lime but without micronutrients was very limited; adding micronutrients to the limed bark overcame the growth-depressing effect of lime, resulting in interaction. The implication of this interaction is that plants have a greater requirement for micronutrients when lime is added. This effect was also reported by Cline et al. (1986) with Prosopis sp. and a peatperlite-vermiculite substrate, in which micronutrient additions had a greater effect on growth in the presence of high (3.6 and $\left.6.0 \mathrm{~kg} \cdot \mathrm{m}^{-3}\right)$ than low $\left(0\right.$ and $\left.1.2 \mathrm{~kg} \cdot \mathrm{m}^{-3}\right)$ lime. Thus, if pine bark contains lime or if bark $\mathrm{pH}$ is relatively high, a micronutrient amendment may be nec- essary to supply extra micronutrients for improved growth.

Amending pine bark with lime impacted other solution bark chemical components in addition to $\mathrm{pH}$ and micronutrient, $\mathrm{Ca}$, and $\mathrm{Mg}$ concentrations. It also increased $\mathrm{NO}_{3}-\mathrm{N}$ concentrations while reducing $\mathrm{NH}_{4}-\mathrm{N}$ levels (Table 5). This response was expected because of the increase in nitrification rates (conversion of $\mathrm{NH}_{4}-\mathrm{N}$ to $\mathrm{NO}_{3}-\mathrm{N}$ ) associated with lime additions and the subsequent increase in substrate pH (Niemiera and Wright, 1986). Argo and Biernbaum (1997) showed that substrate $\mathrm{pH}$ did not affect $\mathrm{N}$ uptake by Impatiens wallerana Hook. F., and that growth of these plants was unaffected by the $\mathrm{NH}_{4}-\mathrm{N}: \mathrm{NO}_{3}-\mathrm{N}$ ratio. This result further supports the hypothesis that the growth responses to lime and micronutrients in our work were due to a micronutrient effect and the amount of available nutrient elements present in solution.

Substrate solution element concentrations in Expts. 1 and 2 (Table 5) and leaf tissue element concentrations in Expt. 1 (Table 6) were higher in high than in low $\mathrm{pH}$ bark. Bark type had less effect on growth in Expt. 1 than in Expt. 2, perhaps because of the lower initial pH of both bark types in Expt. 1 (4.7 and 5.1 vs. 5.1 and 5.8 in Expt. 2). Final bark pH (for both bark types) was 5.1 in Expt. 1 and 6.1 in Expt. 2 . In spite of the drift upward in $\mathrm{pH}$, the overall pH range was lower in Expt. 1 than in Expt. 2. This would result in more available micronutrients in both bark types because of reduced precipitation and adsorption of the nutrients to the bark particle. Thus, at a relatively low $\mathrm{pH}$, the inherent micronutrient supply may be sufficient to produce marketable plants.

A micronutrient $\times$ bark interaction (Fig. 1A), the most common interaction for growth data in both experiments (Tables 1 and 2), indicated that the increase in growth due to micronutrient additions was greater for high $\mathrm{pH}$ than for low $\mathrm{pH}$ bark. Without micronutrients, growth was less in the high $\mathrm{pH}$ bark than in the low $\mathrm{pH}$ bark, which provided higher solution micronutrient concentrations (Table 5). Hence, adding micronutrients overcame the growth-depressing effect of the high $\mathrm{pH}$. Bark $\mathrm{pH}$ and the resultant bark solution nutrient concentrations were the primary factors affecting growth.

In conclusion, the greatest growth of all species occurred in bark amended with micronutrients. Amending bark with lime had no effect on growth. Species used in this experiment represent a wide range of landscape trees from seven plant families. Thus, the common practice of liming pine bark was found to be unnecessary for many seedling tree species grown in the $\mathrm{pH}$ range of these experiments, and was even detrimental to growth by raising the $\mathrm{pH}$ and making any micronutrients present in the substrate less available for plant uptake. An important consideration in our methodology was that our irrigation water had $\mathrm{Ca}$ and $\mathrm{Mg}$ concentrations of 10.2 and $4.2 \mathrm{mg} \cdot \mathrm{L}^{-1}$, respectively. The dramatic response to micronutrients indicates that lack of micronutrients in pine bark in the $\mathrm{pH}$ range of these experiments limits growth, thereby necessitating a 
micronutrient amendment. Although plants consistently responded positively to micronutrient additions, the importance of this amendment may depend on substrate $\mathrm{pH}$. The effect of micronutrients on growth was greatest at relatively high $\mathrm{pH}(>5.2)$ and in combination with liming. If bark $\mathrm{pH}$ is relatively low (4.0 4.2), a micronutrient amendment may be unnecessary, or the rate of additions may be lower than commonly recommended. Addition of lime increased substrate solution $\mathrm{pH}$; this in turn reduced substrate solution and shoot tissue concentrations of nutrients, which ultimately reduced growth.

\section{Literature Cited}

Argo, W.R. and J.A. Biernbaum. 1997. Lime, water source, and fertilizer nitrogen form affect medium $\mathrm{pH}$ and nitrogen accumulation and uptake. HortScience 32:71-74.

Brady, N.C. 1990. The nature and properties of soils. 10th ed. Macmillan, New York.

Chrustic, G.A. and R.D. Wright. 1983. Influence of liming rate on holly, azalea, and juniper growth in pine bark. J. Amer. Soc. Hort. Sci. 108:791-795.

Cline, G., D. Rhodes, and P. Felker. 1986. Micronutrient, phosphorus and $\mathrm{pH}$ influences on growth and leaf tissue nutrient levels of Prosopis alba and Prosopis glandulosa. For. Ecol. and Mgt. 16:81-93.

Daniels, W.L. and R.D. Wright. 1988. Cation exchange properties of pine bark growing media as influenced by $\mathrm{pH}$, particle size, and cation species. J. Amer. Soc. Hort. Sci. 113:557-560.

Leda, C.E. 1986. Iron and manganese requirements of containerized plants growing in pine bark. MS Thesis, Virginia Polytechnic Inst. and State Univ., Blacksburg.

Mengel, K. and E.A. Kirkby. 1987. Principles of plant nutrition. Intl. Potash Inst., Bern, Switzerland.

Niemiera, A.X., T.E. Bilderback, and C.E. Leda 1994. Pine bark physical characteristics influence pour-through nitrogen concentrations. HortScience 29(7):789-791.
Niemiera, A.X. and R.D. Wright. 1986. Effect of liming rate on nitrification in a pine bark medium. J. Amer. Soc. Hort. Sci. 111:713-715.

Sartain, J.B. and D.L. Ingram. 1984. Influence of container medium, lime, and nitrogen source on growth of woody ornamentals. J. Amer. Soc. Hort. Sci. 109:882-886.

SAS Institute. 1985. SAS user's guide: Statistics. 5th ed. SAS Inst., Cary, N.C.

Starr, K.D. and R.D. Wright. 1984. Calcium and magnesium requirements of Ilex crenata 'Helleri'. J. Amer. Soc. Hort. Sci. 109:857-860.

Wright, R.D. and L.E. Hinesley. 1991. Growth of containerized eastern red cedar amended with dolomitic limestone and micronutrients. HortScience 26:143-145.

Yeager, T.H. and D.L. Ingram. 1983. Influence of dolomitic limestone rate on growth of holly, juniper, and azalea, p. 49-51. In: Proc. Southern Nurserymen's Assn. Res. Conf.

Yeager, T.H., R.D. Wright, and S.J. Donohue. 1983. Comparison of pour-through and saturated pine bark extract N, P, K, and pH levels. J. Amer. Soc. Hort. Sci. 108:112-114. 